\title{
Cluster Analysis Menggunakan Algoritma Fuzzy C-means dan K-means Untuk Klasterisasi dan Pemetaan Lahan Pertanian di Minahasa Tenggara
}

\author{
Jemaictry Tamaela $^{1}$, Eko Sediyono $^{2}$, Adi Setiawan ${ }^{3}$ \\ ${ }^{1,2}$ Magister SistemInformasiUniversitas Kristen SatyaWacana \\ ${ }^{3}$ Fakultas Sain dan Matematika, Universitas Kristen Satya Wacana \\ Jl. Diponegoro 52-60 Salatiga, 50711

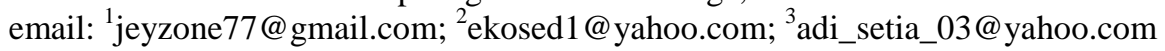

Masuk: 13 Mei 2017; Direvisi: 12 Juni 2017; Diterima: 21 Juni 2017

\begin{abstract}
The purpose of this study is to perform cluster analysis and implementation by utilizing fuzzyc-means (FCM) and k-means (KM) to process agricultural data based on the data mining results. The fuzzy c-means (FCM) and $k$-means $(K M)$ are implemented to find out and form the agricultural land clusters which appropriate the commodity types based on the supporting attributes that are used. The analysis and implementation results could provide some land information such as the number of the clusters, the land areas, the region areas, the locations and the productivity levels. The results of this study could be applied as the suggestion in converting the land functions and structuring the agricultural lands. The utilization of Openstreetmap is an open source solution which is implemented in the application. It could give visual information related to the agricultural land regions based on the clusters which make it easier to comprehend.
\end{abstract}

Keywords: Cluster analysis, C-means, K-means, GIS, Data mining

\begin{abstract}
Abstrak. Penelitian ini bertujuan untuk melakukan analisis cluster dan implementasinya dengan menggunakan algoritma fuzzy c-means (FCM) dan kmeans (KM) untuk mengelola data pertanian dari hasil data mining yang dilakukan. Fuzzy c-means (FCM) dan k-means (KM) dimplementasikan untuk menemukan dan membentuk klaster-klaster daerah lahan pertanian sesuai dengan jenis komoditi berdasarkan atribut-atribut pendukung yang digunakan. Hasil analisis dan implementasi dapat menyediakan informasi lahan seperti jumlah kluster, luas lahan, luas daerah, letak dan tingkat produktifitas. Hasil yang diperoleh dapat menjadi bahan masukan dalam proses alih fungsi dan penataan lahan pertanian. Penggunaan Openstreetmap merupakan solusi open source yang diimplementasikan pada aplikasi dapat memberikan informasi visual daerahdaerah lahan pertanian berdasarkan klaster yang dihasilkan sehingga lebih mudah untuk dipahami.
\end{abstract}

Keywords: Cluster analysis, c-means, $k$-means, GIS, Data mining

\section{Pendahuluan}

Daerah Minahasa Tenggara (MiTra) merupkan salah satu kabupaten di Sulawesi Utara yang baru dimekarkan pada tahun 2010. Luas daerah MiTra 730,62 $\mathrm{km}^{2}$ dan didominasi daerah yang bergunung dengan kesuburan tanah yang tinggi. MiTra menjadikan pertanian sebagai salah satu sektor unggulan dalam menunjang perekonomian daerahnya. Sebagai salah satu daerah pertanian di wilayah Sulawesi Utara, lahan-lahan pertanian terutama untuk sektor tanaman pangan perlu diperhatikan sehingga dapat menunjang kebutuhan pangan dan ekonomi daerah.

Analisis dan pengelolaan lahan pangan perlu dilakukan sehingga dapat memaksimalkan fungsi dan alokasi lahan yang ada untuk memperoleh hasil yang maksimal. Sistem informasi geografis (GIS) dapat memberikan keuntungan yaitu gambaran lahan pangan dari sudut yang 
berbeda, panduan pengolahan lahan pangan, dan informasi pendukung keputusan yang dapat digunakan untuk tindakan yang akan dilakukan (Kisilevich, dkk., 2013).

Salah satu cara yang dapat dilakukan untuk mengelola data geografis lahan adalah dengan melakukan clustering menggunakan algoritma fuzzy c-means (FCM) dan k-means (KM). Fuzzy clustering melakukan pembobotan terhadap tingkat keanggotaan himpunan fuzzynya (Bezdek \& Dunn, 1975). FCM merupakan metode pengelompokan yang memungkinkan satu bagian data memiliki dua atau lebih kelompok (Dunn, 1973). Dengan FCM, objek akan cenderung dibagi menjadi anggota suatu kelompok sesuai derajat keanggotaannya (Jansen, 2007). K-means (KM) dikembangkan oleh McQueen pada 1967. KM merupakan algoritma clustering yang populer dan bekerja dengan cara membagi data ke dalam partisi data (Juanying, dkk., 2011).

Analisis clustering dengan menggunakan algoritma FCM dan KM dapat digunakan untuk mempermudah proses klasterisasi lahan pertanian berdasarkan jenis dan atribut yang telah ditentukan. Selain itu, hasil analisis dan implementasi dapat menjadi bahan pertimbangan dalam proses analisis dan pengambilan keputusan terkait alih fungsi dan alokasi lahan diwaktu yang akan datang. Penggunaan Algoritma FCM dan KM bertujuan untuk membandingkan variasi hasil kluster yang dihasilkan kedua algoritma dalam implementasinya pada aplikasi yang dibuat berdasarkan pada banyaknya jumlah data yang tersedia.

Berdasarakan latar belakang yang telah dijelaskan, maka dilakukan penelitian mengenai cluster analysis dan implementasinya menggunakan algoritma FCM dan KM untuk klasterisasi dan pemetaan lahan pertanian untuk lahan pertanian di Minahasa Tenggara. Implementasi dilakukan dalam bentuk aplikasi desktop.

\section{Tinjauan Pustaka}

\subsection{Penelitian Terdahulu}

Beberapa penelitian terdahulu berkaitan dengan analisis clustering dengan algoritma FCM dan KM diantaranya dilakukan Ali, dkk. (2008) melakukan review dan analisis algoritmaalgoritma clustring yang efektif dalam Segmentasi citra terutama pada citra berbasis fuzzy. Vendruscolo \& Kaleita (2011) menerapkan FCM untuk menghitung data spasial pertanian dengan tujuan mengetahui jumlah klaster optimal dari tanaman yang homogen, proses ini divalidasi menggunakan dua atribut yaitu Partition Coefficient $(P C)$ dan Classification Entropy $(C E)$ and Dunn's Index (DI). Meskipun hanya menggunakan dua atribut tetapi telah menunjukan hasil yang menjanjikan. Martino \& Sessa (2009) menerapakan extended fuzzy cmeans yang merupakan alternatif dari FCM ke dalam GIS untuk menentukan daerah-daerah titik panas. Afifah, dkk. (2016) menerapkan algoritma FCM untuk pengklasteran lahan sawah di Indonesia sebagai evaluasi ketersediaan produksi pangan. Hardiani, dkk. (2014) menggunakan algoritma FCM dan RFM dalam proses data mining untuk customer relationship management dalam kajian data mining customer relationship management pada lembaga keuangan mikro. Rodrigues \& Cora (2015) menerapkan algoritma FCM dalam melakukan identifikasi manajemen lahan berdasarkan variabilitas tanah dan lahan jagung.

Miyamoto (2011) melakukan penelitian tentang perbedaan fungsi-fungsi objek dalam algoritma FCM dan Kernel-Based Clustering. Ghosh \& Dubey (2013) melakukan analisis dan perbandingan performa algoritma KM dan FCM dalam implementasinya pada perangkat lunak. Sankoh, dkk. (2015) menerapkan kombinasi algoritma Neural Network, KM dan Particle Swarm Optimization untuk melakukan klasterisasi jenis musik. Ong (2013) menerapkan algoritma KM dalam penelitiannya untuk menentukan strategi marketing President University. Dalam penelitiannya menggunakan tiga atribut yaitu asal, jurusan dan GPA. Tujuan dan hasil penelitian ini digunakan untuk membantu tim promosi dalam memprediksi strategi promosi yang akan dilakukan oleh President University di Indonesia.

Selain dengan algoritma FCM dan KM, dilakukan proses data mining untuk mengelola data-data geografis MiTra yang akan digunakan sebagai basis data pada proses klusterisasi. Lanzi, dkk. (2012) dalam penelitian Data Mining in GIS: A Novel Context-Based Fuzzy Geographically Weighted Clustering Algorithm menyebutkan sistem informasi geografis (GIS) 
memegang peranan penting dalam berbagai penelitian dan industri. Penelitian dilakukan untuk menemukan aspek-aspek penting data mining dalam GIS dengan menggunakan GIS clustering dengan analisis Geo-Demographic. Penelitian yang dilakukan Kaur, dkk. (2014) dengan menerapkan algortima KM dan K-Nearest Neighbor (KNN) dalam data mining pertanian untuk memprediksi harga tanaman. Peng, dkk. (2011) dalam penelitian An incident information management framework based on data integration, data mining, and and multi-criteria decision making, menyebutkan pentingnya integrasi data suatu kejadian yang sejenis dalam satu format yang sama. Kemudian dengan menggunakan teknik data mining dapat diidentifikasi pelayanan yang sesuai untuk keadaan sebelum dan sesudah kejadian dalam sistem manajemen informasinya.

Berdasarkan tinjauan pustaka yang ada maka dalam penelitian ini akan dilakukan cluster analysis dengan menggunakan algoritma fuzzy c-means (FCM) dan k-means (KM) untuk proses klasterisasi dan pemetaan lahan pertanian di kabupaten Minahasa Tenggara.

\subsection{Landasan Teori}

Cluster analysis merupakan pembelajaran tanpa pengawasan. Clustering bekerja dengan menemukan struktur dalam koleksi data yang tidak di label dan mengelompokannya ke dalam kelompok yang saling memiliki kesamaan (Madhulatha, 2012). FCM merupakan metode pengelompokan yang memungkin satu data memiliki dua atau lebih kelompok (Dunn, 1973) dan diperbaiki oleh bezdek tahun 1981. Langkah-langkah dalam FCM dapat dilihat pada Persamaan (1). Untuk setiap nilai $m$ merupakan bilangan asli lebih dari $1, u_{i j}$ adalah derajat keanggotaan dari $x_{i}$ di klaster $j, c_{j}$ merupakan pusat dimensi klaster. Untuk memaksimalkan hasil klaster, dilakukan perulangan dengan memperbarui keanggotaan $u_{i j}$ dan pusat-pusat klaster $c_{j}$ dengan Persamaan (2). Proses perulangan ini berhenti ketika keanggotan dan pusat-pusat klaster tidak lagi berubah atau berpindah dengan Persamaan (3).

$$
\begin{aligned}
& I_{m}=\sum_{i=1}^{N} \sum_{j-1}^{c} u_{i j}^{m}\left\|x_{i}-c_{j}\right\|^{2} \\
& u_{i j}=\frac{1}{\sum_{k=1}^{c}\left(\frac{\left\|x_{i}-c_{j}\right\|}{\left\|x_{i}-c_{k}\right\|}\right)^{\frac{2}{m-1}} \quad c_{j}=\frac{\sum_{i=1}^{N} u_{i j}^{m} \cdot x_{i}}{\sum_{i=1}^{N} u_{i j}^{m}}} \\
& \max _{i j}=\left\{\left|u_{i j}^{(k+1)}-u_{i j}^{(k)}\right|\right\}<\varepsilon
\end{aligned}
$$

Algoritma K-Means (KM), dikembangkan oleh MacQueen tahun 1967, merupakan salah satu algoritma sederhana dalam memecahkan masalah pengelompokan. MacQueen menjelaskan dalam algoritma k-means, dataset dibagi ke dalam beberapa klaster, dan satu data hanya dapat menjadi satu anggota klaster tertentu (MacQueen, 1967). K-means menentukan terlebih dahulu mean atau titik tengah kluster berdasarkan jumlah kluster yang dibuat, kemudian $k$-means membagi data set ke dalam masing-masing kluster berdasarkan nilai yang sama atau yang mendekati nilai tengah kluster (Zijun, 2012). Algoritma ini bertujuan untuk meminimalisasi suatu fungsi objek. Fungsi objek dalam k-means dapat ditentukan dengan Persamaan (4), dimana $\left\|x_{\bar{i}}^{(j)}-c_{j}\right\|^{2}$ merupakan jarak titik data $x_{i}^{(j)}$ dan pusat klaster $c_{j}$ merupakan indikator jarak poin $n$ data dari pusat klaster masing-masing.

$$
I=\sum_{j=1}^{k} \sum_{i=i}^{n}\left\|x_{i}^{(j)}-c_{j}\right\|^{2}
$$


Langkah-langkah dalam algoritma k-means: (1) Menentukan titik k awal pada objek yang akan diklaster. (2) Menetapkan setiap objek dalam kelompok yang memiliki nilai objektif terdekat. (3) Ketika semua objek telah ditetapkan, posisi titik k dihitung kembali. (4) Langkah ke-2 dan ke-3 diulangi sampai tidak lagi berubah.

\section{Metodologi Penelitian}

Penelitian dilakukan melalui beberapa tahap. Tahap pertama yaitu: (1) Tahap studi pendahuluan. Pada tahap ini dilakukan diidentifikasi masalah yang ada. (2) Tahap analisis dan implementasi. Pada tahap ini dilakukan pengumpulan pustaka pendukung dan parameter untuk proses analisis dan implementasi. (3) Tahap kemanfaatan. Pada tahap ini dipelajari manfaat yang dihasilkan dari hasil analisis dan implementasi.

Dalam penelitian ini terdapat beberapa tahapan data mining yang dilakukan. Tahapan ini dilakukan untuk memaksimalkan data-data pertanian MiTra yang dimiliki. Tahapan data mining yang dilakukan dalam penelitian ini: (1) Data cleaning, tahap ini menghapus data gangguan atau yang tidak diperlukan dan mengisi data yang hilang untuk meningkatkan kualitas data (Joshi \& Usha, 2015). (2) Data integrasi, tahap ini menggabungkan berbagai sumber data yang saling berhubungan. Modul integrasi data yang heterogen dan terintegrasi harus disajikan dalam format yang seragam (Peng, dkk., 2011). (3) Pemilihan data, tahap memilih data yang relevan dengan dengan tujuan penelitian. (4) Transformasi data, tahap ini mengubah data menjadi format baru untuk diproses dalam data mining. (5) Data mining, tahap ini menerapkan metode cerdas untuk ekstraksi pola. Pada tahap ini digunakan algoritma FCM dan KM yang di implementasikan dalam aplikasi. (6) Pola presentasi, tahap ini untuk presentasikan pola yang diperoleh.

\section{Hasil dan Pembahasan}

Aplikasi yang dihasilkan dibuat sendiri dengan teknologi .NET framework 4.6 menggunakan bahasa pemrograman C\# dan menggunakan basis data MySQL. Teknologi . NET framework 4.6 digunakan untuk mempermudah pengembangan aplikasi dan sebagai penerjemah agar aplikasi dapat dijalankan oleh sistem. Aplikasi diintegrasikan dengan OpenStreetMap (OSM) API. OSM API disediakan OpenStreetMap dalam format javascript sehingga pengguna dapat melakukan kostumisasi pada peta yang digunakan dan menyediakan akses langsung ke server OpenStreetMap. Integrasi OSM API dengan aplikasi yang dibuat dapat dilihat pada Gambar 1.

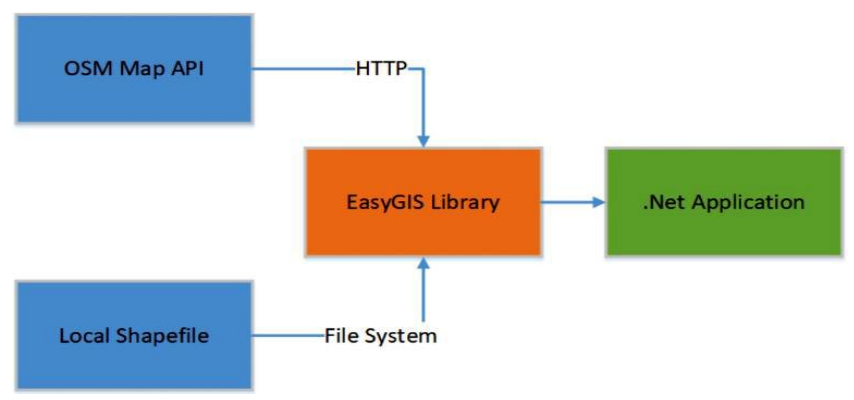

Gambar 1. Integrasi OSM API dengan aplikasi

Aplikasi yang dihasilkan digunakan untuk mengklasterkan lahan pertanian untuk empat komoditi pangan yaitu padi sawah, padi ladang, jagung dan ubi kayu. Hasil data mining dari data-data pertanian MiTra digunakan sebagai basis data untuk proses mining dan klasterisasi melalui aplikasi. Tabel data hasil mining dari data-data MiTra dapat dilihat pada Gambar 2 dan Gambar 3. 


\begin{tabular}{|c|c|c|c|c|c|c|c|c|c|c|}
\hline \multirow[t]{2}{*}{ Wilayah } & \multirow{2}{*}{$\begin{array}{c}\text { Luas } \\
\text { Wilayah (Ha) }\end{array}$} & \multirow[t]{2}{*}{ Penduduk } & \multicolumn{3}{|c|}{ Produksi Padi Sawah } & \multicolumn{3}{|c|}{ Produksi Padi Ladang } & \multicolumn{2}{|c|}{ Model Pengairan Sawah } \\
\hline & & & Luas Tanam (Ha) & Luas Panen $(\mathrm{Ha})$ & Produksi (Ton) & Luas Tanam (Ha) & Luas Panen (Ha) & Produksi(Ton) & Semi Teknis & Sederhana \\
\hline Ratatotok & 10.418 & 12.696 & 18 & 15 & 69 & 117 & 102 & \begin{tabular}{|l|}
317,3 \\
\end{tabular} & 0 & 9 \\
\hline Posumean & 5.362 & 8.392 & 352 & 347 & 1.792 & 15 & 12 & 37,4 & 96 & 150 \\
\hline Belang & 7.517 & 16.290 & 651 & 632 & 3.318 & 45 & 42 & 131 & 115 & 130 \\
\hline Ratahan & 6.163 & 12.981 & 780 & 753 & 3.773 & 15 & 12 & 38 & 276 & 111 \\
\hline Pasan & 4.979 & 6.546 & 527 & 506 & 2.631 & 25 & 22 & 39 & 53 & 120 \\
\hline Ratahan Timur & 6.399 & 5.763 & 146 & 138 & 653 & 50 & 48 & 149 & 0 & 1 \\
\hline Tombatu & 6.795 & 8.870 & 630 & 604 & 3.068 & 110 & 103 & 321 & 184 & 142 \\
\hline Tombatu Timur & 1.881 & 8.690 & 852 & 802 & 3.984 & 30 & 25 & 78 & 317 & 273 \\
\hline Tombatu Utara & 3.717 & 7.773 & 990 & 974 & 4.798 & 0 & 0 & 0 & 0 & 366 \\
\hline Touluaan & 10.180 & 6.420 & 375 & 356 & 1.738 & 0 & 0 & 0 & $\mathbf{0}$ & 275 \\
\hline Touluaan Selatan & 5.276 & 3.910 & 50 & 42 & 194 & 130 & 125 & 389 & 0 & 222 \\
\hline Silian Raya & 4.375 & 5.487 & 512 & 482 & 2.040 & 0 & 0 & 0 & 0 & 241 \\
\hline
\end{tabular}

Gambar 2. Data hasil transformasi

\begin{tabular}{|c|c|c|c|c|c|c|}
\hline \multicolumn{3}{l}{ Produksi Jagung } & \multicolumn{3}{c|}{ Produksi Ubi Kayu } & $\begin{array}{c}\text { Koperasi } \\
\text { Pemasaran }\end{array}$ \\
\cline { 1 - 6 } Luas Tanam (Ha) & Luas Panen (Ha) & Produksi (Ton) & Luas Tanam (Ha) & Luas Panen (Ha) & Produksi (Ton) & 0 \\
\hline 947 & 920 & 3.523 & 25 & 21 & 262 & 0 \\
\hline 885 & 860 & 3.050 & 12 & 8 & 98 & 3 \\
\hline 1203 & 1105 & 3.809 & 18 & 15 & 187 & 0 \\
\hline 852 & 810 & 2.904 & 9 & 5 & 61 & 0 \\
\hline 871 & 842 & 2.975 & 12 & 7 & 88 & 0 \\
\hline 564 & 523 & 1.882 & 8 & 5 & 60 & 0 \\
\hline 387 & 362 & 1.282 & 11 & 8 & 98 & 0 \\
\hline 953 & 915 & 3.027 & 15 & 11 & 141 & 4 \\
\hline 381 & 352 & 1.225 & 8 & 5 & 61 & 4 \\
\hline 320 & 295 & 1.023 & 12 & 7 & 88 & 0 \\
\hline 543 & 512 & 1.728 & 15 & 8 & 98 & 0 \\
\hline 327 & 295 & 1.017 & 20 & 12 & 150 & 0 \\
\hline & & & & & & \\
\hline
\end{tabular}

Gambar 3. Data hasil transformasi

Dalam penelitian ini data yang digunakan sebagai data sample selain data hasil observasi, data-data diperoleh dari data Indikator Kesejahteraan Rakyat Kabupaten Minahasa Tenggara (Badan Pusat Statistik Kabupaten Minahasa Selatan, 2015a) dan data Kabupaten Minahasa Tenggara Dalam Angka tahun 2015 (Badan Pusat Statistik Kabupaten Minahasa Selatan, 2015b) dan data Kabupaten Minahasa Tenggara Dalam Angka tahun 2016(Badan Pusat Statistik Kabupaten Minahasa Selatan, 2016). Aplikasi dibuat dengan tampilan yang sederhana untuk mempermudah user dalam menggunakan aplikasi. Contoh tampilan aplikasi dapat dilihat pada Gambar 4.
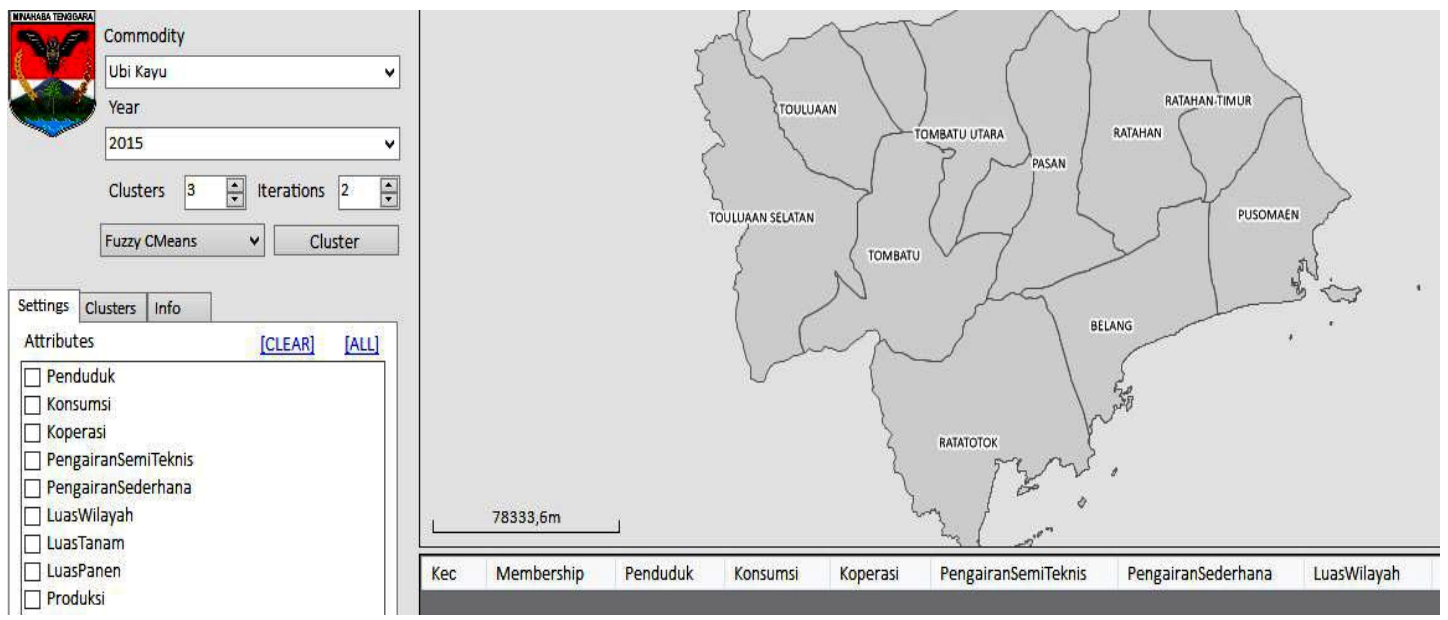

Gambar 4. Tampilan aplikasi

Bagian kiri merupakan fitur utama dari aplikasi yang terdiri dari komoditi, tahun, kluster, iterasi dan algoritma yang diterapkan. Settings berisi atribut yang digunakan dalam proses klasterisasi. Clusters berisi informasi kluster yang dihasilkan. Info berisi informasi atribut yang digunakan dan nilai masing-masing. Untuk menambah data ke dalam aplikasi, disediakan master data. Pada bagian ini, user dapat mengisi dan merubah data-data yang diperlukan sesuai dengan jenis datanya. Contoh master data dapat dilihat pada Gambar 5. 


\begin{tabular}{|c|c|c|c|}
\hline Commodity & Kecamatan & Data Panen & Data Penduduk \\
\hline & Nama & & Luas \\
\hline \multirow[t]{4}{*}{ • } & Belang & & 7517,00000 \\
\hline & Pasan & & 4979,00000 \\
\hline & Pusomaen & & 5362,00000 \\
\hline & Ratahan & & 6163,00000 \\
\hline
\end{tabular}

Gambar 5. Master Data

Pengujian aplikasi dilakukan dengan menggunakan data Minahasa Tenggara. Pengujian dilakukan dengan menggunakan data tahun 2014 yang diperoleh dari data Minahasa Tenggara Dalam Angka Tahun 2015 dengan contoh komoditi jagung berdasarkan atribut luas tanam dan luas panen. Proses pengujian pertama menggunakan algoritma FCM. Contoh hasil kluster yang dihasilkan dengan algoritma FCM dapat dilihat pada Gambar 6.

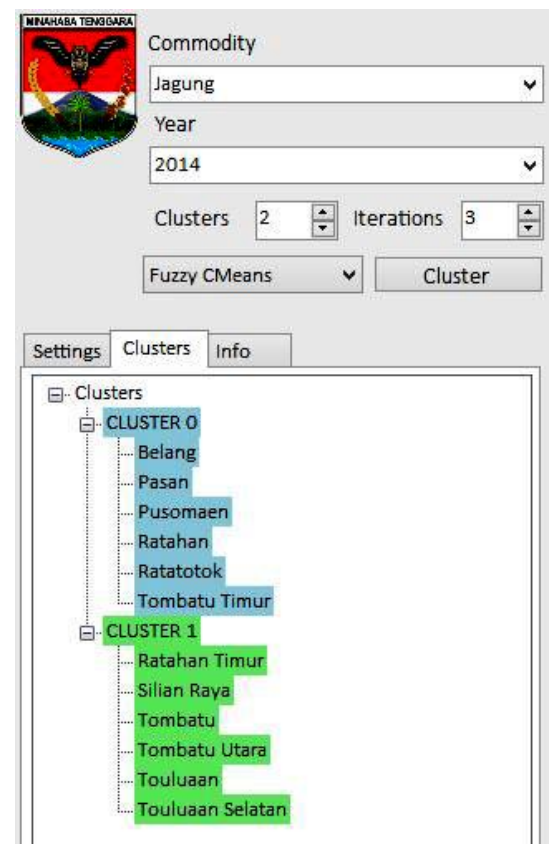

Gambar 6. Hasil kluster FCM

Hasil pada Gambar 6 adalah proses klasterisasi dengan menggunakan dua kluster dengan iterasi sebanyak tiga putaran. Daerah Belang, Pasan, Posumaen, Ratatotok dan Tombatu timur masuk ke dalam klaster nol atau klaster pertama dengan nilai mean klaster untuk luas tanam 793,11 dan luas panen 753,56 ditandai dengan Warna biru. Daerah Ratahan Timur, Silian Raya, Tombatu, Tombatu Utara, Touluaan, Touluaan Selatan merupakan anggota klaster satu atau klaster ke dua dengan nilai mean klaster berdasarkan luas tanam 420,33 dan luas panen 389,83 ditandai dengan warna hijau. Contoh informasi hasil kluster yang berisi nilai membership dan mean masing-masing kecamatan dapat dilihat pada Gambar 7. Dari hasil klusterisasi yang dilakukan, peta hasil kluster yang dihasilkan dapat dilihat pada Gambar 8 .

\begin{tabular}{|l|c||c|c|}
\hline Kec & \multicolumn{1}{c}{ Membership } & LuasTanam & LuasPanen \\
\hline Ratahan Timur & {$[0,42][0,58]$} & 564 & 523 \\
\hline Silian Raya & {$[0,35][0,65]$} & 327 & 295 \\
\hline Tombatu & {$[0,28][0,72]$} & 387 & 362 \\
\hline Tombatu Utara & {$[0,29][0,71]$} & 381 & 352 \\
\hline Touluaan & {$[0,35][0,65]$} & 320 & 295 \\
\hline Touluaan Selatan & {$[0,40][0,60]$} & 543 & 512 \\
\hline -MEAN- & & $\mathbf{4 2 0 , 3 3}$ & $\mathbf{3 8 9 , 8 3}$ \\
\hline
\end{tabular}

Gambar 7. Informasi membership kluster FCM 


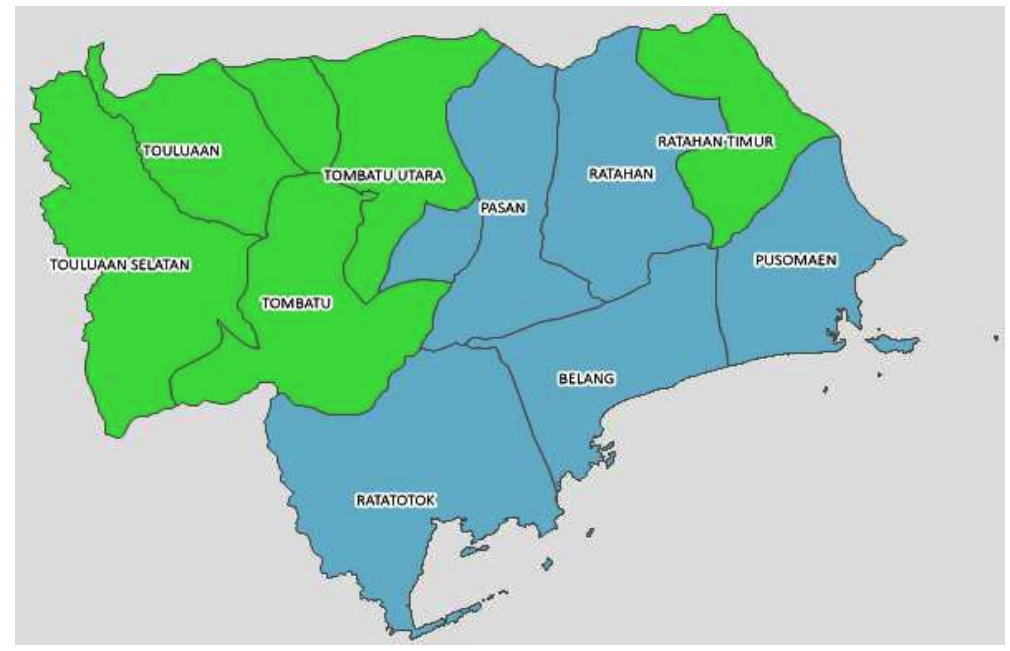

Gambar 8. Peta hasil kluster jagung FCM

Hasil akhir kluster dengan menggunakan algoritma FCM untuk komoditi jagung dengan atribut luas tanam dan luas panen dapat dilihat pada Tabel 1. Dari hasil Tabel 1, karena pada iterasi ke tiga memberikan hasil yang sama dengan iterasi sebelumnya (iterasi ke dua), maka proses iterasi dihentikan pada iterasi ke tiga. Pada percobaan dengan menggunakan tiga kluster, ditemukan adanya kluster kosong atau kluster yang tidak memiliki anggota karena nilai keanggotaan dari masing-masing atribut kecamatan tidak memenuhi kriteria dari klaster tersebut. Dari hasil percobaan dengan menggunkan komoditi jagung berdasarkan luas tanam dan luas panen tahun 2014 maka diperoleh hasil daerah dengan luas lahan pertanian dan panen jagung terbesar berada pada wilayah Belang, Pasan, Posumaen, Ratahan, Ratatotok dan Tombatu Timur, sedangkan wilayah dengan lahan pertanian jagung dan panen terkecil berada di Ratahan Timur, Silian Raya, Tombatu, Tombatu Utara, Touluaan dan Touluaan Selatan.

Tabel 1. Hasil kluster FCM

\begin{tabular}{|c|c|c|c|c|c|c|}
\hline \multirow[t]{2}{*}{ Kecamatan } & \multicolumn{3}{|c|}{ Cluster 0} & \multicolumn{3}{|c|}{ Cluster 1} \\
\hline & 1 & 2 & 3 & 1 & 2 & 3 \\
\hline Belang & $\checkmark$ & & & & $\checkmark$ & $\checkmark$ \\
\hline Pasan & $\checkmark$ & & & & $\checkmark$ & $\checkmark$ \\
\hline Posumaen & $\checkmark$ & & & & $\checkmark$ & $\checkmark$ \\
\hline Ratahan & $\checkmark$ & & & & $\checkmark$ & $\checkmark$ \\
\hline Ratahan Timur & $\checkmark$ & $\checkmark$ & $\checkmark$ & & & \\
\hline Ratatotok & $\checkmark$ & & & & $\checkmark$ & $\checkmark$ \\
\hline Silian Raya & & $\checkmark$ & $\checkmark$ & $\checkmark$ & & \\
\hline Tombatu & & & & $\checkmark$ & $\checkmark$ & $\checkmark$ \\
\hline Tombatu Timur & $\checkmark$ & $\checkmark$ & $\checkmark$ & & & \\
\hline Tombatu Utara & & $\checkmark$ & $\checkmark$ & $\checkmark$ & & \\
\hline Touluaan & $\checkmark$ & $\checkmark$ & $\checkmark$ & & & \\
\hline Touluaan Selatan & $\checkmark$ & $\checkmark$ & $\checkmark$ & & & \\
\hline
\end{tabular}

Pengujian dengan menggunakan algoritma KM dengan menggunakan data tahun 2014, menggunakan komoditi jagung dengan atribut yang berbeda dengan pengujian pertama yaitu luas wilayah dan luas tanam. Pengujian ini dilakukan dengan menggunakan empat kluster dengan iterasi sebanyak tiga kali. Hasil kluster dari aplkasi dengan menggunakan algoritma KM menggunakan empat kluster dapat dilihat pada Gambar 9. Peta yang dihasilkan dari hasil klaster dengan algoritma KM dapat dilihat pada Gambar 10. 


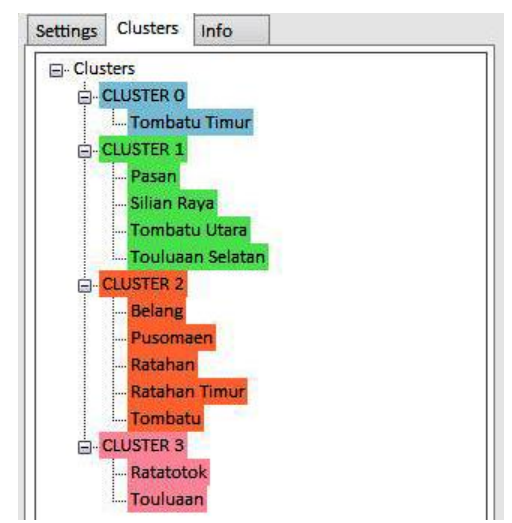

\section{Gambar 9. Hasil kluster dengan algoritma KM dengan empat kluster}

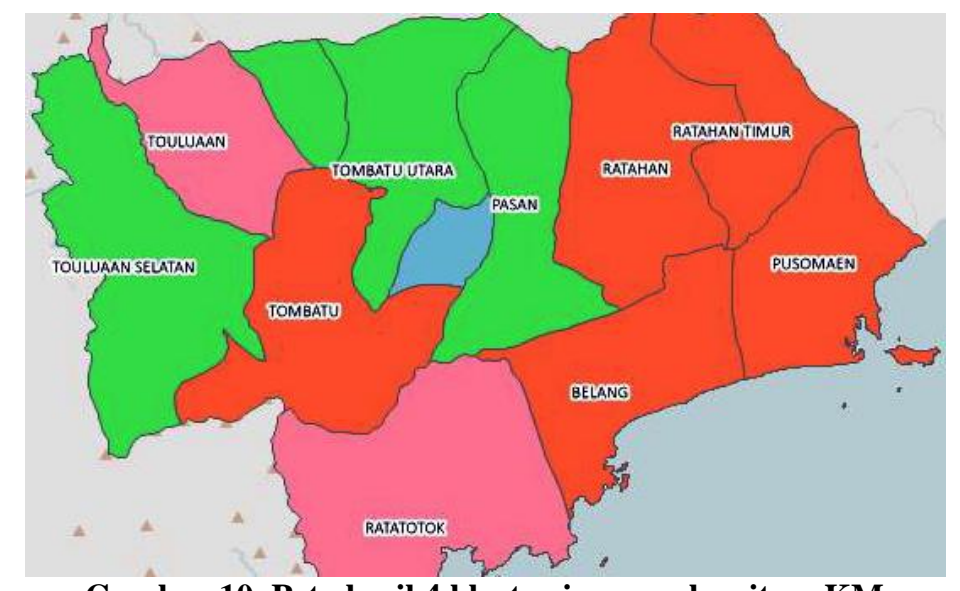

Gambar 10. Peta hasil 4 klaster jagung algoritma KM

Dari peta yang dihasilkan, Tombatu berada dalam kluster sendiri yaitu kluster nol dengan nilai mean kluster berdasarkan luas wilayah 1.881 dan luas tanam 953 ditandai dengan warna biru. Daerah Pasan, Silian Raya, Tombatu Utara dan Touluan berada dalam kluster satu dengan nilai mean kluster berdasarkan luas wilayah 4.568,75 dan luas tanam 530,5 ditandai dengan warna hijau. Daerah Belang, Posumaen, Ratahan, Ratahan Timur dan Tombatu berada dalam kluster dua dengan nilai mean kluster berdasarkan luas wilayah 6.447,2 dan luas tanam 778,2 ditandai dengan warna merah. Daerah Ratatotok dan Touluaan berada dalam kluster tiga dengan nilai mean kluster berdasarkan luas wilayah 10.299 dan luas tanam 633,5 ditandai dengan warna merah muda. Dengan demikian diperoleh hasil kluster lahan pertanian untuk komiditi jagung dengan wilayah terkecil berada di daerah Tombatu dan terbesar berada di daerah Ratatotok dan Touluan. Proses kluster lahan pangan dengan algoritma KM menggunakan empat kluster dengan tiga iterasi dapat dilihat pada Tabel 2.

Tabel 2. Hasil Klaster KM

\begin{tabular}{|c|c|c|c|c|c|c|c|c|c|c|c|c|}
\hline \multirow[t]{2}{*}{ Kecamatan } & \multicolumn{3}{|c|}{ Cluster 0} & \multicolumn{3}{|c|}{ Cluster 1} & \multicolumn{3}{|c|}{ Cluster 2} & \multicolumn{3}{|c|}{ Cluster 3} \\
\hline & 1 & 2 & 3 & 1 & 2 & 3 & 1 & 2 & 3 & 1 & 2 & 3 \\
\hline Belang & & & & & & & & $\checkmark$ & $\checkmark$ & & & \\
\hline Pasan & & & & $\checkmark$ & $\sqrt{ }$ & $\checkmark$ & & & & & & \\
\hline Posumaen & & & & & & & $\sqrt{ }$ & $\checkmark$ & $\checkmark$ & & & \\
\hline Ratahan & & & & & & & $\sqrt{ }$ & $\checkmark$ & $\checkmark$ & & & \\
\hline Ratahan Timur & & & & & & & $\checkmark$ & $\checkmark$ & $\checkmark$ & & & \\
\hline Ratatotok & & & & & & & & & & $\checkmark$ & $\sqrt{ }$ & $\checkmark$ \\
\hline Silian Raya & & & & $\sqrt{ }$ & $\checkmark$ & $\sqrt{ }$ & & & & & & \\
\hline Tombatu & & & & & & & $\checkmark$ & $v$ & $\checkmark$ & & & \\
\hline Tombatu Timur & $\sqrt{ }$ & $\sqrt{ }$ & $\checkmark$ & & & & & & & & & \\
\hline Tombatu Utara & & & & & $\checkmark$ & $\checkmark$ & & & & & & \\
\hline Touluaan & & & & & & & & & & $\checkmark$ & $\checkmark$ & $\checkmark$ \\
\hline Touluaan Selatan & & & & & & & $\checkmark$ & $v$ & $\checkmark$ & & & \\
\hline
\end{tabular}


Dari hasil Tabel 2, diketahui karena pada iterasi ketiga memberikan hasil yang sama dengan iterasi sebelumnya (iterasi kedua), maka proses iterasi dihentikan pada iterasi ketiga. Hasil Tabel 2 menunjukan kluster nol merupakan daerah dengan nilai terendah dan kluster tiga merupakan daerah dengan nilai tertinggi.

\section{Kesimpulan}

Berdasarkan hasil implementasi dan analisis, maka penelitian ini memperoleh kesimpulan, algoritma FCM dan KM yang diimplementasikan pada aplikasi dapat berjalan dengan baik dalam mengklasterkan daerah-daerah lahan pertanian sesuai komoditi berdasarkan pada jenis atribut yang digunakan. Dari berbagai data yang ada, data dalam bentuk angka dipilih untuk digunakan sebagai data pengujian. Hal ini dikarenakan data angka dapat dihitung nilai mean atau rata-ratanya. Selain itu pada penelitian FCM dan KM hanya dapat diimplementasikan untuk memproses data dalam bentuk angka.

Pada pengujian, proses iterasi maksimal didapat pada iterasi ketiga karena pada iterasi selanjutnya tidak terjadi perubahan anggota kluster. Hal ini dipengaruhi oleh banyaknya jumlah data yang tersedia. Dengan jumlah data yang terbatas, algoritma KM dapat bekerja lebih baik dibandingkan FCM dengan menghasilkan jumlah kluster yang lebih banyak atau bervariasi.

Aplikasi yang dihasilkan mudah digunakan dalam proses pengisian data, pemilihan komoditi, penentuan banyaknya klaster, jumlah iterasi yang diperlukan, visualisasi dan pemilihan atribut-atribut yang dapat disesuaikan dengan kebutuhan user. Hasil yang diperoleh dapat menjadi masukan kepada pemerintah daerah MiTra dalam mengelola dan memaksimalkan potensi lahan pertanian daerah.

Penggunaan Openstreetmap merupakan solusi open source yang dapat digabungkan dengan aplikasi sehingga dapat memberikan informasi visual daerah-daerah pertanian berdasarkan klaster yang dihasilkan sehingga lebih mudah untuk dipahami. Selain memperoleh data dalam bentuk angka, user juga memperoleh gambaran letak daerah berdasarkan peta yang dihasilkan.

\section{Saran}

Dari keseluruhan pemaparan yang dijelaskan sebelumnya dalam penelitian, dapat disimpulkan bahwa pada penelitian ini dilakukan proses klasterisasi dan pemetaan lahan pertanian pangan daerah MiTra sehingga dapat diketahui daerah-daerah pertanian berdasarkan komoditi dan atributnya. Untuk dapat memaksimalkan hasil penelitian, perlu dilakukan kajian lebih lanjut dengan memperhitungkan kemiringan lahan, struktur tanah, kecocokan komoditi dengan tanah lahan, potensi bencana dan banyaknya daerah aliran sungai (DAS) yang dapat digunakan dalam menunjang lahan pertanian. Hal ini juga perlu dilakukan sehingga alih fungsi lahan menjadi lahan pertanian lain atau pemukiman penduduk dapat dilakukan dengan tepat sehingga daerah yang memiliki potensi lahan pertanian yang tinggi dapat dimanfaatkan dengan maksimal. Kajian ini yang belum dilakukan dalam penelitian ini dikarenakan keterbatasan waktu dan data yang tersedia.

\section{Referensi}

Afifah, N., Rini, D.C., Lubab, A. (2016). Pengklasteran Lahan Sawah di Indonesia Sebagai Evaluasi Ketersediaan Produksi Pangan Menggunakan Fuzzy C-Means. Jurnal Matematika "MANTIK", 2 (1).

Ali, M.A., Karmakar, G.C., \& Dooley, L.S. (2008). Review On Fuzzy Clustering Algorithm. IETECH Journal Of Advance Computations, 2 (3), 169-181.

Badan Pusat Statistik Kabupaten Minahasa Selatan. 2015a. Indikator Kesejahteraan Rakyat Kabupaten Minahasa Tenggara 2015. Badan Pusat Statistik Kabupaten Minahasa Selatan.

Badan Pusat Statistik Kabupaten Minahasa Selatan. 2015b. Minahasa Tenggara Dalam Angka Tahun 2015. Badan Pusat Statistik Kabupaten Minahasa Selatan. 
Badan Pusat Statistik Kabupaten Minahasa Selatan. 2016. Minahasa Tenggara Dalam Angka Tahun 2016. Badan Pusat Statistik Kabupaten Minahasa Selatan.

Bezdek, J.C., \& Dunn, J.C. (1975). Optimal fuzzy partitions: A heuristic for estimating the parameters in a mixture of normal dustrubutions. IEEE Transactions on Computers, 835-838.

Bezdek, J.C. (1981). Pattern Recognition with Fuzzy Objective Function Algorithms, Plenum Press, New York.

Dunn, J. C. (1973). A Fuzzy Relative of the ISODATA Process and Its Use in Detecting Compact Well-Separated Clusters. Journal of Cybernetics, 3, 32-57

Ghosh, S., \& Dubey, S.K. (2013) Comparative Analysis of K-Means and Fuzzy C-Means Algorithms. International Journal of Advance Computer Science and Aplications (IJACSA), 4 (4).

Hardiani. T., Sulistyo. S., \& Hartanto. R. (2014). Kajian Data Mining Customer Relationship Management Pada Lembaga Keuangan Mikro.S2 Teknik Elektro dan Teknologi Informasi, Universitas Gadjah Mada Yogyakarta. Jurnal Sistem Informasi Bisnis Undip 3 .

Joshi, S., \& Usha, T. (2015). Data Cleaning Using Based Data Mining Technique. International Journal of Emerging Trends \& Technology in Computer Science (IJETTCS), 4 (2).

Juanying, X., Shuai, J., Wexin, X., \& Xinbo, G. (2011). An Efficient Global K-means Clustering Algorithm. Journal of Computer, 6 (2).

Kaur, M., Gulati, H., \& Kundra, H. (2014). Data Mining in Agricultur on Crop Price Prediction: Techniques and Application. International Journal of Computer Applications, 99 (12).

Kisilevich, S., Keim, D., \& Rokach, L. (2013). A GIS-based decision support system for hotel room rate estimation and temporal price prediction: The hotel brokers ontext. Journal Decision Support Syst, 54, 1119-1133.

Lanzi, P. L., Cuong, B. C., Hung, H. A., \& others. (2012). Data Mining in GIS: A Novel Context-Based Fuzzy Geographically Weighted ClusteringAlgorithm. International Journal of Machine Learning and Computing, 2(3), 235.

MacQueen, B.J. (1967): "Some Methods for classification and Analysis of Multivariate Observations, Proceedings of 5-th Berkeley Symposium on Mathematical Statistics and Probability".

Madhulatha, T.S. (2012). An Overview On Clustering Methods. IOSR Journal of Engineering, $2(4), 791-725$

Martino, F.D., \& Sessa, S. (2009). Implementation of the Extended Fuzzy C-Means Algorithm in Geographic Information System. Journal of Uncertain System,3 (4), 298-306.

Miyamoto, M. (2011). Different Objective Function Functions in Fuzzy C-means Algorithms and Kernel-Based Clustering. International Journal of Fuzzy System, 13 (2).

Ong, J.O. (2013). Implementasi algoritma K-means Clustering Untuk Menentukan Strategi Marketing President University. Jurnal Ilmiah Teknik Industri (JITI) 12 (1), 10-20.

Peng, Y., Zhang, Y., Tang, Y., \& Li, S. (2011). An incident information management framework based on data integration, data mining, and multi-criteria decision making. Decision Support Systems, 51(2), 316-327.

Rodrigues, E.S., \& Cora, J.E. (2015). Managemen Zones Using Fuzzy Clustring Based On Spatial-Temporaal Variability Of Soil And Corn Yield. Journal of the Brazilian Association of Agricultural Engineering Journal, 3, 470-483.

Sankoh, A.S., Musthafa, A.R., Rosidi, Imron, M., \& Arifin, A.Z. (2015). Klasterisasi Jenis Musik Menggunakan Kombinasi Neural Network, K-Means dan Particle Swarm Optimization. Journal Buana Informatika, 6 (3).

Vendruscolo, L.G., \& Kaleita, A.F. (2011). Modeling Zone Management in Precision Agriculture Through Fuzzy C-means Technique at Spatial Database. Digital Repository, Iowa State University.

Zijun, Z. (2012). K-mean algorithm cluster analysis in data mining. 